\title{
HOMØOSTATISK INTENTIONALITET VS. EPISTEMISK KOHÆRENS
}

\author{
Hvorfor fri vilje og prædestination går hånd $\mathrm{i}$ hånd i religiøse systemer
}

\author{
Uffe Schjødt
}

\begin{abstract}
ENGLISH ABSTRACT: It is often assumed that religious world views are coherent systems of ideas. The fact that religious subjects easily adopt conflicting propositions contradicts this assumption. In this paper I will argue that religious ideas do not have to be mutually coherent in order to survive in religious systems. In fact it is necessary for the religious subject to adopt conflicting ideas in order to cope with all aspects of life. I suggest that we assume functional coherency instead of epistemic coherency in religious systems, and I predict that a functional approach using concepts and typologies from coping psychology to analyse religious ideas, will make researchers able to gain new insights on the relation between religious concepts. This prediction is supported by a preliminary analysis of the notions of free will and predestination, illustrating how coping psychology provides the tools necessary for explaining the problem of conflicting propositions.
\end{abstract}

DANSK RESUME: Balkanisering er det fanomen, at mennesker tilsyneladende kan leve med indbyrdes modstridende forestillinger i et religiøst verdensbillede, uden at disse modsigelser problematiseres. Fanomenet er en torn i øjet på religionsvidenskaben, der ofte antager at mennesker i en kultur opfatter religiøse forestillinger som et epistemisk sammenhongende system. I denne artikel argumenterer jeg for, at religiøse forestillinger ikke behøver at voere indbyrdes kohorente for at overleve i den troendes forestillingsverden. Tvartimod, for at afhjcelpe individet $i$ alle livets aspekter, er det nødvendigt at bryde med systemets indbyrdes kohcerens og åbne for produktionen af optimale strategier designet til at løse specifikke problemer.

KEYWORDS: Epistemic coherency, World views, Emotion, Homeostasis, Conceptualization, Coping,

\section{Det kohærente verdensbillede}

Temaet $\mathrm{i}$ foreliggende jubilæumsnummer er balkaniseringen af religiøse systemer. Balkanisering er det fænomen, at mennesker tilsyneladende kan leve med indbyrdes modstridende forestillinger i et religiøst verdensbillede, uden at disse modsigelser problematiseres. Temaet bliver aktuelt med antagelsen om det kohærente verdensbillede, nemlig 
tanken om, at mennesker i en kultur opfatter religiøse forestillinger som et epistemisk sammenhængende system. Antagelsen findes i forskellige berøringsflader med religionsvidenskaben: Den findes i religionshistorien, hvor det antages, at hver religion udgøres af et system af ideer og begreber, hvis sammenhæng kan beskrives, når blot kildematerialet er detaljeret nok. Den findes i etnografiske studier, hvor det antages, at myter og ritualer kan forstås i et sammenhængende verdensbillede, når blot beskrivelsen af den pågældende kultur er rig nok. I klassiske eksempler, hvor tvillinger hævdes at være fugle og agurker erstatter okser i ritualer, kan det være svært at få øje på rationalet $\mathrm{i}$ religiøse systemer; men det viser sig ofte, at umiddelbart modsætningsfyldte propositioner alligevel giver mening, når de bagvedliggende antagelser er tilstrækkeligt belyst. Antagelsen om, at der findes et kohærent verdensbillede bag en hver religion, er interessant nok en af de sjældne præmisser, som religionsvidenskaben deler med både teologer og almindeligt praktiserende religiøse mennesker.

Der findes flere forklaringer på, hvorfor tanken om det kohærente verdensbillede har domineret religionsvidenskaben. Tre forklaringer virker særligt relevante for balkaniseringsfænomenet. For det første er religiøse systemer i overensstemmelse med det sociologiske paradigme næsten eksklusivt blevet behandlet på gruppeniveau. Individuelle forskelle i opfattelsen af religiøse ideer og praksis på tværs af køn, alder, personlighed og social status er blevet ignoreret som støj på et ellers klart signal. For det andet er religiøse forestillinger blevet tolket i overensstemmelse med klassiske symbol- og begrebsteorier, hvor symboler opfattes som stabile strukturer, der efter tilegnelse repræsenteres ens i og imellem individer. For det tredje er indbyrdes modstridende forestillinger enten blevet opfattet som lokale variationer eller som resultatet af historiske udviklinger inden for det samme verdensbillede.

\section{Balkaniseringsproblemer}

I dag er de tre præmisser bag teorien om det kohærente verdensbillede imidlertid kommet $i$ kraftig modvind. Problemerne er opstået, fordi indsigter fra sociologien samt personligheds-, emotions-, og kognitionsforskningen peger i retning af en langt mindre stabil og langt mere dynamisk begrebsverden end den, som understøtter tanken om det kohærente verdensbillede både mellem individer og i forskellige kontekster. Jeg vil i det følgende præsentere nogle af de væsentligste erkendelser fra disse områder, men først vil jeg give en kort afklaring af den kognitive religionsvidenskabs position i balkaniseringsdebatten.

\section{Kognitivt intermezzo}

Ifølge Pascal Boyer er religiøse forestillinger minimalt modintuitive repræsentationer, som knytter an til abduktive inferenskæder, der trækker på en række naturlige domæner $i$ bevidstheden. Det er med andre ord begrebernes kognitive kvaliteter, der afgør, om en ide aktiveres, og om den overlever i hjernen eller ej. Dette er en tanke, som er udbredt i den aktuelle kognitive religionsvidenskab.

Boyer hævder, at man i princippet kan forstå et religiøst system, hvis man kombine- 
rer en 'rig' beskrivelse af de stabile processer i bevidstheden med sociologiens 'rige' beskrivelser af de kulturelle systemer (thick descriptions). Vi besidder herudfra et endeligt antal kognitive domæner, som kun kan tilsættes modintuitive aspekter på et bestemt antal måder. I teorien kan dette forklare, hvorfor visse religiøse forestillinger er stærkere end andre, og hvorfor visse forestillinger overlever, mens andre forsvinder. Men teorien forklarer ikke, hvorfor visse forestillinger aktiveres i nogle situationer og ikke i andre, og hvordan indbyrdes modstridende forestillinger kan overleve parallelt $\mathrm{i}$ bevidstheden uden at udkonkurrere hinanden. ${ }^{1}$ Boyers opgør med den klassiske antropologi begrænser sig derved til integrationen af kognitive indsigter i forståelsen af dannelsen og transmissionen af religiøse begreber. Begreberne er lige så stabile og kohærente som i den klassiske begrebsteori. Den eneste ændring i begrebsopfattelsen er, at de universelle kognitive kapaciteter nu opfattes som en begrænsende faktor i begrebsdannelsen. Boyer tilbyder altså ingen forklaring på balkaniseringen af religiøse systemer eller den dynamik i og imellem individer, som er afgørende for fænomenet. Det er med andre ord ikke nok at integrere kognitionsforskningens indsigter i opgavespecifikke inferenssystemer og universelle bevidsthedsmoduler, hvis man vil forstå balkaniseringen af religiøse systemer. Den eneste måde at forstå fænomenet på er, som jeg vil argumentere for i de følgende afsnit, at erkende begrebers idiosynkratiske aspekter, hvor fysiologiske tilstande og emotioner dominerer de kognitive processer.

\section{Personlighedsforskning}

Allerede $\mathrm{i}$ begyndelsen af forrige århundrede påpegede William James, at forskellige personlighedstyper korrelerede med forskellige religiøse forestillinger inden for det samme religiøse system (James 1902): den optimistiske type med en åben tilgang til verden fokuserer ofte på de propositioner i kristendommens dogmer, der fremstiller verden som grundlæggende god, mens den pessimistiske personlighedstype har en tendens til at fokusere på kristendommens forestillinger om straf, synd og helvedesild. De deler begge kristendommens bekendelsesgrundlag og dogmer, men som James bemærker (James 1902, 88), synes den positive tilstand i optimisten i sig selv at udelukke pessimistens negative verdensbillede.

Jeg har før vist, at James' hypoteser om forholdet mellem religiøse forestillinger og personlighed understøttes af moderne indsigter fra copingpsykologien (Schjødt 2006). At religiøsitet moduleres af personlighed, er desuden i overensstemmelse med indsigter fra personlighedsforskningen, hvor forskellige faktorer, som både er genetiske og miljøbestemte, har vist sig at være effektive prædiktorer for, hvordan individet forholder sig til verden (fx introvert og ekstrovert adfærd, Costa \& McCrae 2003). Hvordan disse faktorer specifikt spiller ind i mobiliseringen af forskellige forestillinger inden for det samme religiøse system er stadig dårligt belyst, men teoretiske tiltag er begyndt at vinde frem (Koenig et al. 2001).

\footnotetext{
${ }^{1}$ I Boyers teori er det netop den religiøse forestilling, der giver bedst mening i det kognitive apparat, der vinder konkurrencen om pladsen i bevidstheden og overlever i det religiøse system.
} 
Begrebsdynamik og kontekst

Religiøse forestillinger udgøres af symboler, begreber og kategorier. I klassiske symbolog begrebsteorier (fra Gottlob Freges begrebsfilosofi og frem til Eleanor Rosch's prototypeteori), er disse blevet betragtet som strukturer, hvis grænser og indhold er relativt stabile både i og imellem individer. I dag ved vi, at repræsentationen af begreber er kontekstafhængig og idiosynkratisk. En stol kan indgå i arbitrære kategorier afhængigt af konteksten, fx ting man salger $i$ en garage. Der findes hverken en begrebsmæssig kerne eller noget stabilt hierarkisk system af subordinate og superordinate kategorier ( $\mathrm{fx}$ lænestol - stol - møbel), som indplacerer begrebet i et stabilt system. Begreber er dynamiske størrelser, der repræsenteres og kategoriseres i situationen ud fra de parametre, der er til stede internt som kropslige og mentale tilstande og eksternt i omgivelserne.

Perceptionspsykologen Lawrence Barsalou kalder begreber for simulatorer. Simulatorer indeholder alle de aktiviteter i hjernen, som kan aktiveres ved repræsentationen af et begreb (Barsalou 1999). Men det er kun en brøkdel af disse, som rent faktisk aktiveres i den enkelte situation, hvor konteksten kun fordrer relevante aspekter af simulatoren. Disse situationsspecifikke begrebsdannelser kalder Barsalou for simulationer. Begrebet HUND indeholder fx en række semantiske og sansemæssige aspekter, fx våd snude, logrende hale, vågne ører, blød pels, gøen og fire ben; men det indeholder desuden et fysiologisk aspekt, der markerer, hvordan subjektet tidligere har forholdt sig til det repræsenterede begreb i en situation. Fysiologiske tilstande i simulationer af begreber, herunder emotioner, er derfor dynamiske og varierer ud fra et hav af kontekstsensitive variable, hvilket gør repræsentationen af fx HUND til en altid foranderlig størrelse. Jeg argumenterer i det følgende for, at det er de emotionelle tilstande i repræsentationen af begreber, der gør, at indbyrdes modstridende aspekter i det religiøse forestillingsbillede uproblematisk mobiliseres i forskellige situationer. Men først lidt mere om, hvordan emotioner virker i begreber.

\section{Emotioner og begrebers funktion}

Neurobiologen Antonio Damasio indførte i 1994 begrebet somatiske markører for at beskrive de idiosynkratiske aspekter, som individet integrerer i begreber gennem erfaring med omverden. En somatisk markør er alle de fysiologiske reaktioner, individet aktiverer i repræsentationen af et bestemt begreb. Disse reaktioner er ikke stabile, men dynamiske, og de ændrer sig fra situation til situation, bestemt ud fra hvilke erfaringer vi gør os. Lige som repræsentationen af begrebet HUND ikke indeholder perceptuelle associationer til en PUDDELHUND, hvis konteksten er et skilt med en hundeadvarsel i en mørk gyde, så afhænger begrebets somatiske markører ligeledes af konteksten.

I en mørk gyde vil repræsentationen af en DOBERMANN være sandsynlig, og de somatiske reaktioner vil være hjertebanken snarere end afslappethed. Hjertebanken er i dette tilfælde ikke støj i en ellers rationel begrebsdannelse. Tværtimod giver somatiske reaktioner som hjertebanken begrebet en helt central betydning for individets tilpasning til situationen. At forestille sig en frådende dobermann, hvis man står i en mørk gyde, er en effektiv tilpasningsstrategi, for så vidt begrebet aktiverer kroppens frygt-reaktioner, 


\section{Homøostatisk intentionalitet vs. epistemisk kohærens}

fx øget ilttilførsel, øget blodgennemstrømning og udvidede pupiller. Alle disse reaktioner hører nemlig til den såkaldte fight-or-flight respons, som hjælper os i forberedelsen på mødet med en trussel. Ved repræsentationen af en dobermann forbereder individet sig altså til situationen både fysisk og mentalt.

Det emotionelle aspekt $\mathrm{i}$ begreber giver på den måde begrebet en vital funktion for det repræsenterende subjekt, og det er her balkaniseringsfænomenet bliver aktuelt. Det at man uproblematisk kan splitte et begreb $i$ to indbyrdes modstridende repræsentationer, er nemlig helt afgørende for forberedelsen til specifikke situationer. Lad mig forklare: Hvis begrebsdannelsen i den mørke gyde indeholdt alle tænkelige aspekter ved begrebet HUND, fx repræsentationer af en puddelhund, ville vi ikke opnå den optimale tilstand i forhold til konteksten, fordi den kropslige reaktion på repræsentationen af en puddelhund, for så vidt den aktiverer glæde, ville modarbejde frygt-reaktionen direkte ved at aktivere processer, der mindsker ilttilførslen og mindske blodgennemstrømningen (dvs. afslapning). ${ }^{2}$ En kontekstuafhængig begrebsdannelse i den mørke gyde ville altså rent fysiologisk modarbejde individets forberedelse på mødet med en trussel. Af den grund er vi i stand til at fortrænge eller hæmme signalet for irrelevante aspekter i en kategori og fremhæve andre for at optimere vores adfærd til en bestemt kontekst. Dynamiske begrebsdannelser er skræddersyede til specifikke situationer, hvor de effektivt medvirker til at tilpasse og forberede os fysisk og mentalt til mulige scenarier i fremtiden.

\section{Coping}

Optimering, forberedelse, tilpasning og opretholdelse af organismen er aspekter ved individets grundlæggende reaktion på de udfordringer, det konstant møder i hverdagen. Begreber med somatiske markører indgår heri som byggesten i komplekse processer som beslutninger, planlægning, behovsudskydelse og epistemiske overvejelser, når vi udsættes for udfordringer i form af nyt job, sygdom, eksamener, rejser, konflikter, ægteskab, fødsel, pubertet, dødsfald etc. Disse grundlæggende reaktioner på udfordringer i fortid, nutid og fremtid kaldes i psykologien for coping.

I psykologien skelnes der mellem to hovedtyper af coping, hvoraf den ene fokuserer på mestring af omgivelserne, mens den anden fokuserer på subjektets mentale tilstand. Schwarzer \& Knoll opererer med yderligere to dimensioner i deres copingtypologi, nemlig tid og sandsynlighed, hvilket gør dem i stand til at opstille fire forskellige copingtyper:

\footnotetext{
${ }^{2}$ Fight-or-flight-systemets modsætning kaldes rest-and-digest, og det dominerer i situationer, hvor vi ikke umiddelbart har brug for at være beredte. Fight-or-flight og rest-and-digest er populære udtryk for henholdsvis de sympatiske og parasympatiske dele af det autonome nervesystem.
} 


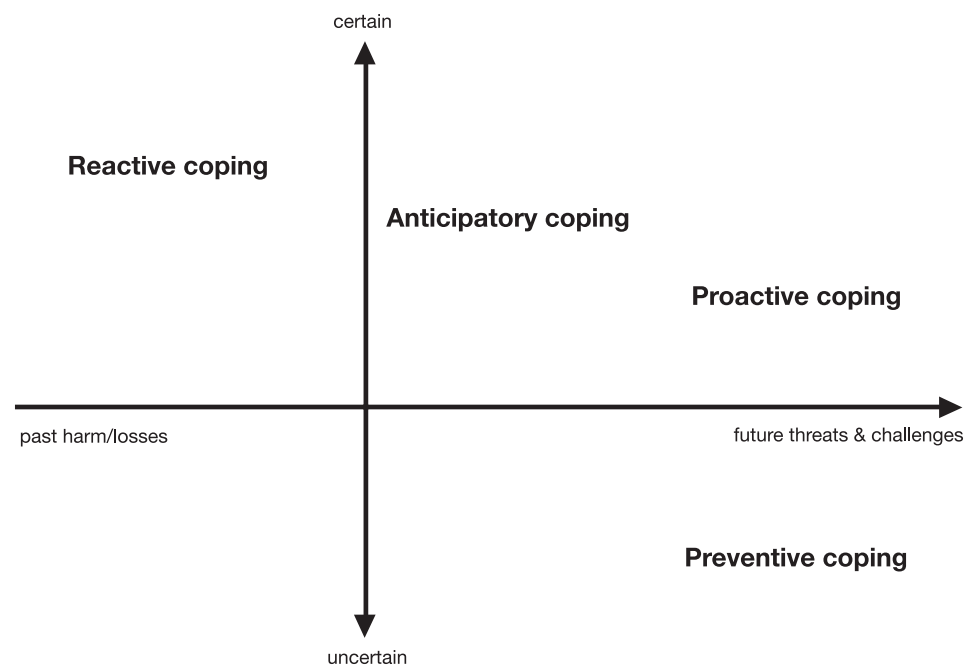

(Gengivelse af Schwarzer \& Knolls model 2003, 394)

Reaktiv coping er individets forsøg på at løse problemer, der allerede er opstået. En diagnose, en skilsmisse, en fyring eller et dødsfald kræver dels nye vaner og livsstil, og dels et nyt syn, som kan give mening til de ændrede omstændigheder.

Anticipatorisk coping forbereder individet på umiddelbart forestående udfordringer fx en eksamen, et tandlægebesøg, en rejse, en ny status i samfundet (fra student til uddannet, fra ungkarl til forælder, fra arbejder til pensionist etc.). Forberedelsen kan bestå $i$ at øve sig på en forestående udfordring, fx ved at læse på pensum. Mentalt kan individet ændre opfattelsen af udfordringen til en kontrollerbar begivenhed, $\mathrm{fx}$ ved at underdrive vigtigheden af en forestående eksamen.

Proaktiv coping optimerer individet til begivenheder og situationer, der kan forventes at ske i fremtiden, $\mathrm{fx}$ en ændret økonomisk status, nye krav til voksenlivet, alderdom, død osv. Optimeringen består fx i at uddanne sig, betale til pensionsordning og generelt forbedre de kvaliteter, som med stor sandsynlighed bliver vigtige senere i livet. Mentalt kan proaktiv coping bestå i at se de udfordringer, der med sikkerhed opstår i fremtiden, som muligheder frem for begrænsninger, $\mathrm{fx}$ at få børn, at børnene flytter hjemmefra, at blive ældre osv.

Prceventiv coping søger at komme eventuelle udfordringer i fremtiden i forkøbet, $\mathrm{fx}$ en fyring, en ulykke, en sygdom eller et røveri. Præventive strategier kan være at følge sikre rutiner, at forsikre sig selv og sin ejendom, at spare penge sammen eller lære selvforsvar. Mentalt kan præventiv coping være at neddrosle risikoen for at blive ramt af sygdom eller røveri ved fx at gøre sig statistiske overvejelser eller ved at acceptere tilfældigheden.

Jeg har valgt at beskrive copingtypologien uden at give religiøse eksempler på de fire mulige copingstrategier, men som det formodentlig er fremgået, er det oplagt at inddele religiøse forestillinger og ritualer i typologiens fire strategier. Jeg nøjes i det føl- 
gende med et enkelt eksempel.

\section{Fri vilje og Prædestination - en test case}

Forestillingerne om den fri vilje og prædestination i det protestantiske gudsforhold kan tolkes ud fra Schwarzer og Knolls copingtypologi. ${ }^{3}$ De to forestillinger står som indbyrdes modstridende forklaringer på det samme problem, nemlig, hvorfor vores liv arter sig, som det gør, og de eksisterer begge i det samme religiøse system, nemlig, det kristne verdensbillede. ${ }^{4}$ Alligevel benyttes de uproblematisk af de fleste kristne i Danmark, hvilket gør dem til et fint eksempel på balkaniseringsfænomenet. Ved at indsætte de to forestillinger i Schwarzer \& Knolls model viser det sig imidlertid, at forestillingerne supplerer hinanden i et funktionsorienteret system snarere end at være konkurrerende strategier i et epistemisk sammenhængende system.

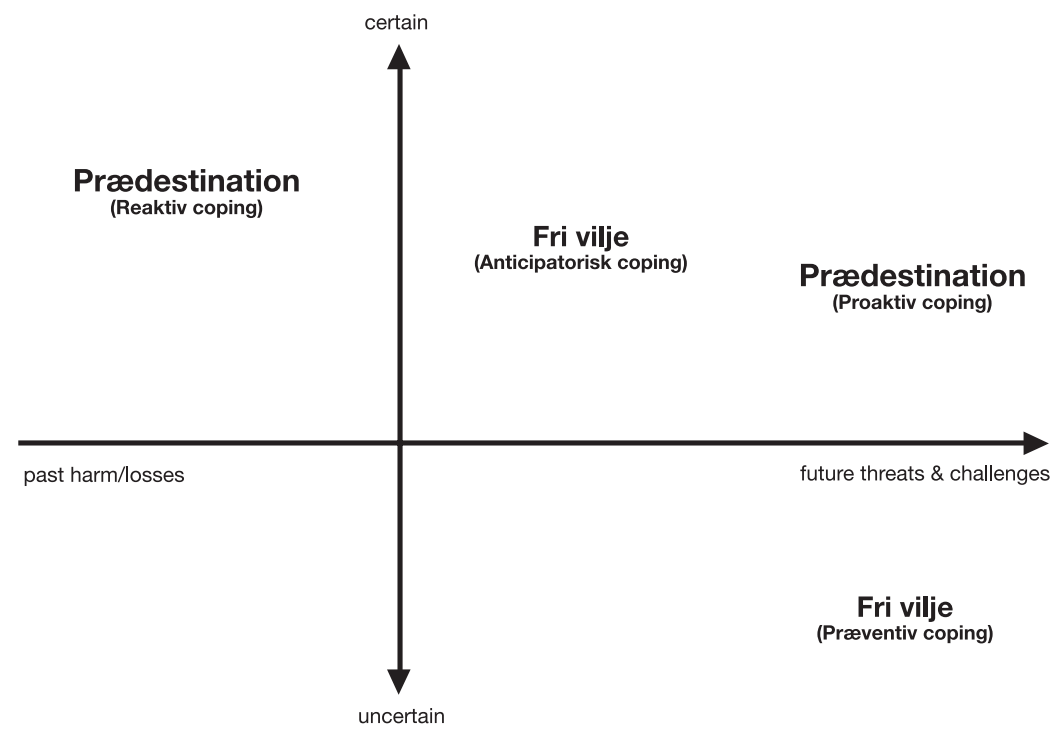

Under reaktiv og proaktiv coping er udfordringen enten indtruffen eller vil med stor sandsynlighed indtræffe i fremtiden. At have en guddom, der kontrollerer disse begivenheder, er en positiv copingstrategi, fordi subjektet står magtesløs over for de generelle livsvilkår (Pargament \& Brant 1998, 119-20). Under anticipatorisk og prceventiv coping er en forestående handling eller en forebyggende strategi afgørende for udfaldet. I situationer, hvor subjektet har handlemulighed, vil motivationen til 'gode' handlinger styrkes ved antagelsen om ikke-sekulær belønning eller straf, fx himmel/helvede, og

${ }^{3}$ Schwarzer \& Knolls typologi beskæftiger sig kun med positiv coping dvs. strategier, der har en positiv effekt på individet.

${ }^{4}$ Paradokset mellem prædestination og fri vilje findes ikke kun i det kristne verdensbillede, men også i bl.a. islam jf. Imerli Perhos bidrag. 
mobiliseringen af fri vilje korrelerer derfor med positiv coping (jf. Pargament \& Brant 1998, 121). Hvis begge forestillinger derimod indgår som religiøs forklaring uanset situationens kontekst, vil de to forestillingers forskellige funktioner modarbejde hinanden som i eksemplet med den frådende dobermann og den nuttede puddelhund. Den fri vilje styrker motivationen til at træffe det rigtige valg i situationer, hvor handling er mulig; men den svækker prædestinationens tryghed i situationer, hvor individet står magtesløs over for begivenhedernes gang. Det er derfor nødvendigt at være i stand til at hæmme den ene forestilling, så den anden kan fungere optimalt i situationen.

Eksemplet skal ikke ses som en egentlig analyse af forholdet mellem antagelsen om fri vilje og prædestination i fx et protestantisk gudsforhold, men som et illustrativt eksempel på, hvordan begrebsdynamikkens funktion kan forestilles at fungere i mere komplekse religiøse forestillinger. Der skal ikke herske tvivl om, at der er langt fra forholdet mellem dobermannen og puddelhunden til oscillationen mellem fri vilje og prædestination; men mit forslag er, at ligesom ved begrebsdynamikken, hvor visse aspekter fremhæves $i$ en situation, mens andre aspekter hæmmes, er udformningen af effektive copingstrategier på bekostning af indbyrdes kohærens nødvendig for at optimere funktionen af religiøse systemer.

Der findes flere paradoksale forestillinger inden for kristendommen. Klassiske problemstillinger som teodicé (Gud som den algode og almægtige skaber), treenig monoteisme (Gud som Fader, Søn og Helligånd) og ideen om den dobbelte udgang (prædestination og fri vilje) er fremtrædende eksempler. De kan alle deles op i aspekter, som enkeltvis rummer forestillinger, der fungerer som effektive strategier i specifikke situationer, hvis andre aspekter i forestillingen hæmmes. Det ville være interessant at analysere disse ud fra copingpsykologiens og begrebsdynamikkens funktionelle og organismeorienterede udgangspunkt.

\section{Online og Offline religiøsitet}

Jeg har frem til nu beskæftiget mig med den religiøse adfærd, der anvendes i det daglige møde med tilværelsen. Jeg vil hævde, at i mindst 95 procent af tiden lever den troende med de religiøse systemer uden at overveje de epistemiske konsekvenser af forholdet mellem de enkelte forestillinger. Bortset for teologer og religionsvidenskabsmænd er denne form for Online-adfærd uden tvivl den dominerende. De resterende 5 procent, som ikke bruges online i mødet med de daglige udfordringer, kan vi kalde for Offlineadfærd. Offline-religiøsitet repræsenterer de situationer, hvor selve det religiøse system er udfordringen. I Offline-situationer skaber de religiøse systemers indbyrdes modstridende forestillinger kognitiv dissonans som reaktion på en særlig begivenhed. I situationer, hvor individet oplever en krise, fx sorg ved dødsfald, kan tanker om de paradoksale antagelser i systemet frembringe en epistemisk krise, fx teodicé-problemet (hvorfor findes der ondt, når Gud har skabt alt og samtidig er algod?). Den troende kan så vælge at konsultere præsten, øge sin kirkelige aktivitet og reflektere over trosbekendelsen og de forkyndte ord, indtil problemet går i sig selv. Herefter genoptages den daglige online-adfærd, og de indbyrdes modstridende forestillinger lever atter uproblematisk side 
om side. Det er værd at bemærke, hvor problemfrit overgangen fra religiøs krise til daglig religiøs praksis kan foregå, og hvor sjældent det sker, at den troende opnår en permanent afklaring af de paradoksale forestillinger.

Eksemplet er groft simplificeret; men pointen er, at offline-religiøsitet ikke er primær, men sekundær i den troendes religiøse praksis. Epistemisk kohærens nedprioriteres i situationer, hvor den troende forholder sig til en konkret udfordring (som ikke er det religiøse system selv), og det gør den troende det meste af tiden. Alligevel er det offline-religiøsiteten, som i lang tid har haft religionsvidenskabens og særligt religionshistoriens opmærksomhed. Den daglige, funktionsorienterede online-adfærd, som dominerer det religiøse menneskes praksis, er blevet opfattet som idiosynkratisk støj på en epistemisk kohærent linje. I lyset af indsigterne fra personligheds-, emotions- og kognitionsforskningen mener jeg, at dette misforhold simpelthen er en tendens, der bør rettes op på.

\title{
6. Konklusion
}

Temaet i dette jubilæumsnummer af Religionsvidenskabeligt Tidsskrift er foranlediget af det problem, der opstår, når religionshistorikere og sociologer antager, at religiøse systemer er epistemisk kohærente. Balkaniseringen viser nemlig, at troende langt fra praktiserer religion ud fra et epistemisk kohærent verdensbillede. Men hvordan skal vi som religionsforskere forholde os til det fænomen, at religiøse mennesker tilsyneladende ikke bekymrer sig om sammenhængen mellem det religiøse systems enkelte forestillinger? Skal vi acceptere, at de fleste religiøse mennesker bare ikke forstår den store sammenhæng i deres egen religion, eller må vi som forskere ændre opfattelse af, hvad religiøse systemer overhovedet er for en størrelse?

Jeg argumenterer for, at de selvmodsigelser, der findes i religiøse systemer, har deres egen slags kohærens. Indbyrdes modstridende religiøse forestillinger er netop et symptom på, at der findes en anden form for sammenhæng. De er ikke støj i et epistemisk sammenhængende verdensbillede, men en nødvendig konsekvens af menneskets stræben efter optimale strategier til effektivt at løse udfordringer i specifikke situationer.

Jeg forudsiger, at en analyse af forskellige kulturers religiøse systemer vil afsløre, at der sandelig er en sammenhæng mellem de enkelte forestillinger, og at tanken om organismens homøostatiske intentionalitet, dvs. organismens stræben efter tilpasning, optimering og opretholdelse af individet, er en effektiv tolkningsnøgle til at forstå disse sammenhænge.

\author{
Litteratur \\ BARSALOU, LAWRENCE W. \\ 1999 "Perceptual symbol systems", Behavioral and Brain Sciences Vol. 22 (4), 577-660. \\ BOYER, PASCAL \\ 1994 The Naturalness of Religious Ideas, University of California Press, Berkeley.
}


Costa, PAul R \& RoBert T. McCrae

2003 Personality in Adulthood: a five-factor theory perspective, Guilford Press, New York.

DAMASIO, ANTONIO

1994 Descartes' Error: Emotion, Reason, and the Human Brain, Penguin Putnam. New York.

JAMES, WILLIAM

1902 The Varieties of Religious Experience: A Study of Human Nature, Longmans, Green \& Co., London.

KoENiG, HaROLd G. ET AL.

2001 Handbook of Religion and Health, University Press, Oxford.

PARGAMENT, K. I \& C.R. BRANT

1998 "Religion and Coping”, i: Harold G. Koenigs, ed., Handbook of Religion and Mental Health, Academic Press, California, 112-126.

SCHJøDT, UFFE

2006 'Heuristisk klassiker eller cutting-edge religionsvidenskab? Om William James' generelle psykologiske og specifikke religionspsykologiske hypoteser", Chaos 46 (under udgivelse).

SCHWARZER, R. \& KNOLL, N.

2003 "Positive Coping: Mastering Demands and Searching for Meaning", i S.J. Lopez, \& C.R. Snyder, eds, Positive Psychological Assessment, American Psychological Association. Washington D.C., 393-409.

Uffe Schjødt

Ph.d.-studerende

Afdeling for Religionsvidenskab

Aarhus Universitet 